\title{
A Strong-Motion Database of Costa Rica: 20 Years of Digital Records
}

Aarón Moya-Fernández ${ }^{\mathrm{a}}$, Luis A. Pinzón ${ }^{\mathrm{b}}$, Victor Schmidt-Díaz ${ }^{\mathrm{a}}$, Diego Hidalgo-Leiva ${ }^{\mathrm{a}}{ }^{*}$ and Luis G. Pujades $^{\mathrm{b}}$

${ }^{a}$ Earthquake Engineering Laboratory, Universidad de Costa Rica, San José, Costa Rica

${ }^{\mathrm{b}}$ Department of Civil and Environmental Engineering, Universitat Politècnica de Catalunya, Barcelona, Spain

*Contact information of correspondence author:

Diego Hidalgo-Leiva, Ph.D.

Address: Laboratorio de Ingeniería Sísmica, Ciudad de la Investigación, Universidad de Costa Rica, San Pedro, San José, Costa Rica

Mobile phone: +506 2511-6675

Email: diego.hidalgo@ucr.ac.cr 


\section{Abstract}

2 In this paper, we present a strong-motion database from earthquakes recorded by the Earthquake Engineering

3 Laboratory at the University of Costa Rica. The database consists of 2471 three-component accelerograms from 155

4 digitally recorded events. It covers the last 20 years of measurements, including records from the Nicoya earthquake

5 of Mw 7.6 on 2012 September 05. The engineering and seismological communities can use this data either to conduct

6 new research or to improve seismic or hazard studies in the region. A catalog is also available with metadata of each

7 record containing several intensity measures from the ground-motion time-histories.

\section{Introduction}

9 The convergence of the Cocos and Caribbean plates along the Pacific coast of Costa Rica is the major 10 source of seismic activity for the country (Alvarado et al., 2017; Arroyo et al., 2017). As a result, many 11 earthquakes occur along the subduction zone as well as active volcanism in the continental part. The outer

12 slope side of the place generates normal faulting while reverse faulting takes place at depths between 15

13 and 50 km (Quintero and Güendel, 2000; DeShon et al., 2003; Norabuena et al., 2004). At depths between

1450 and $280 \mathrm{~km}$, intraplate or intra-slab earthquakes (deep subduction) occur and in general normal type 15 mechanisms predominate (Guendel and Protti, 1998).

16 The Benioff zone gets shallower in the southern part of Costa Rica, where the Cocos mountain range

17 subducts. The Panama Fracture Zone is a dextral fault system that separates the Cocos plate from the Nazca

18 plate (Schmidt-Díaz, 2014). At the southern end of the Burica Peninsula lies the triple junction where the

19 Cocos, Caribbean and Panama block meet. There is also a high number of seismic events that take place

20 along the Northern Panama Deformed Belt (NPDB) and Central Costa Rica Deformed Belt (CRDB). These

21 are a series of cortical deformation zones with a high density of active faults (Goes et al., 1993; Guangwei

22 Fan et al., 1993; Montero, 2001). This complex tectonic framework has resulted in numerous destructive

23 earthquakes (i.e., 1991 Limon $M_{w}$ 7.7; 2012 Nicoya $M_{w}$ 7.6), and, consequently, a concern to develop and 24 improve the seismic hazard and risk studies of the country. 
The Earthquake Engineering Laboratory at the University of Costa Rica (LIS-UCR for its acronym in

26 Spanish) started operations in 1983. That year, the United States Agency for International Development

27 (USAID), donated several SMA-1 Kinemetrics strong-motion accelerographs to Costa Rica. They were

28 located along the Pacific coast and the highly populated Central Valley. That was known as the Faculty of

29 Engineering's Accelerographic Network. It was an analog network, which meant that after a strong 30 earthquake took place, the collection and processing of the information took several days to weeks to get 31 ready for analysis.

32 In 1989 the name was changed to LIS-UCR. New digital instruments were acquired, and the geographic 33 coverage of the stations increased. At the time of writing this document, the LIS-UCR has more than 160 34 digital, 24-bit strong-motion units located in free-field conditions, boreholes, and inside buildings. The LIS35 UCR is in charge of recording, processing and storing all acceleration records for academic and research 36 purposes. The accelerograms used in this document were recorded only by sensors in free-field conditions.

37 The time span for the database provided in this paper ranges from 1998 to the present. The objective of this 38 article is to give an overview and provide easy access to this database, and therefore, expanding its use on 39 research.

\section{Strong-Motion Network}

41 The strong-motion network of the LIS-UCR began operating in 1983 with the installation of SMA-1

42 Kinemetrics analog sensors. In June 1991, digital processing started with the installation of several SSA-2

43 Kinemetrics type sensors. In 2010 many analog instruments were replaced by Ref Tek technology, and in

442012 Güralp and Nanometrics sensors were also added to the network. Nowadays, there are a total of 130

45 free-field stations [most of them with FBA (force-balanced-accelerograph) sensors, but MEMS (Micro-

46 Electro-Mechanical Systems) as well] as shown in figure 1.

47 There are four soil types according to the Costa Rican Seismic Code (CRSC) (CFIA, 2016). This 

soil) and S4 (very soft soil). There is no F type of soil in the CRSC classification.

51 Due to the complexity of data acquisition and the cost of the geotechnical studies, we used the classification

52 method proposed by Zhao et al. (2006). The results can be found in Schmidt-Díaz (2011). The method is

53 based on the horizontal-to-vertical (H/V) 5\% damped response spectral ratio. From that, the fundamental 54 period can also be obtained. We then used a classification index for each station. When available, geological and geotechnical information was also used as a reference. very soft soil (S4), and $7.7 \%$ as rock sites (S1). In order to get a better site characterization, we are also conducting MASW measurements to define the Vs30 parameter. Currently, 35 stations have Vs30 and we are conducting measurements in 30 more stations (data available upon request via email). Figure 2 shows the site classification described above. There is also a table with a summary of the site conditions available 61 at the LIS-UCR website (see Data and Resources).

\section{Strong-Motion Database}

63 The strong-motion database we present here has a total of 2471 three-component accelerograms. They 64 correspond to 155 earthquakes recorded from 1998 to the present. The database is being updated 65 automatically with new events as they trigger the Accelerographic Monitoring System (SMA in Spanish, 66 Moya-Fernández, 2018). Figure 3 shows the distribution of ground motion recordings per year. The number 67 has increased in recent years because at present there are more stations.

68 The SMA threshold requires that 30 stations surpass a value of 10 defined as follows: Every 15 seconds the 69 SMA computes the PGA at every station for the last 60 seconds and stores its value. Only the NS component 70 is used. It compares the PGA from the current minute $\left(P G A_{C}\right)$ and the previous one $\left(P G A_{P}\right)$. If the ratio $71\left(P G A_{C} / P G A_{P}\right)$ is larger than 10 in 30 sites, the SMA processing begins. PGA is computed for the three 72 components of every station once the SMA gets activated using the whole waveform. Once the SMA closes 
the event, we select the records that have at least one horizontal PGA greater than 2 gals in order to include them in the final database.

The earthquake's location (coordinates in WGS84 system), depth, and magnitude are calculated automatically by the SMA (Moya-Fernández, 2018). The magnitude used to characterize the database is the moment magnitude $\left(M_{w}\right)$. Table 1 shows a statistical summary of the number of records per different ranges of magnitude, depth, and epicentral distance. Figure 4a shows the relation magnitude vs hypocentral distance. The hypocentral distance for the events in the database ranges from 5 to $400 \mathrm{~km}$. There are 1509 records from earthquakes with $M_{w} \geq 5(61.1 \%)$ (see Figure $4 \mathrm{~b}$ ). Figure 5 shows the location of the events in the database. Only one of the recorded earthquakes has an $M_{w}>7$, the $7.6 M_{w}$ Nicoya earthquake of 2012. A total of 71 stations recorded that event which shook the whole country. The largest peak ground acceleration was $1.6 \mathrm{~g}$ at GNSR station, which was the closest to the epicenter (Schmidt-Díaz et al., 2014).

The LIS-UCR stores strong-motion data in an ASCII format called "lis-format" (Moya-Fernández, 2006). This is a special type of format developed for researchers and students to have access to time-series data.

The files contain a header of 34 lines with relevant station and earthquake information of each record, after which there are the three independent columns corresponding to the north-south (N00E), vertical (UPDO), and east-west (N90E) component. Metadata from the header includes the earthquake source (subduction or local), site to event distance [epicentral $\left(R_{e p i}\right)$, hypocentral $\left(R_{h y p o}\right)$, Joyner-Boore $\left(R_{j b}\right)$ and the closest distance to rupture $\left(R_{r u p}\right)$ ], site condition, soil classification, among others. The $R_{j b}$ and the $R_{r u p}$ were computed following the methodology proposed by Thompson and Worden (2018). Earthquake source information is given in the database as local (LOCAL) or subduction (SUBDU) type events. This classification is a general one, and it is based on the epicenter location and depth. Earthquakes located place along the Pacific coast are usually classified as subduction type events. Earthquakes further inland in the rest of the country at shallow depths (less than $30 \mathrm{~km}$ ) are classified as local ones. Deeper earthquakes (more than $30 \mathrm{~km}$ ) along the subducted Cocos plate are classified as intraslab (INSLB) events. We use "UNDEF" for those earthquakes happening in complex tectonic settings or where a simple classification 
cannot be made. The slab model for Central America from USGS was used to help define which events happened along the subducted slab in Costa Rica (Hayes et al., 2012). This metadata is available in a catalog on the LIS-UCR website (see Data and Resources).

\section{Data Processing}

Each station transmits real-time data to the LIS-UCR servers in miniSEED format. When an earthquake is strong enough to trigger 30 stations, the SMA extracts a pre-defined time-window and converts waveform data to SAC format (Goldstein et al., 2003) in $\mathrm{cm} / \mathrm{s}^{2}$. A baseline correction is applied by removing the mean value. After tapering on both ends, a second-order Butterworth bandpass filter is used. The SMA then processes the source parameters, calculate peak values, and gathers station information and soil type to save data into lis-format. Notice that the entire process is automatic, for that reason, the data is later inspected by eye in order to identify events with a low signal-to-noise ratio or with processing issues. Records that are not suitable are removed from the database.

Data processing is proposed to satisfy the requirements of an Engineering Strong Motion (ESM) database. Frequency bandpass is set to include and overcomes the frequency range for civil structures. Over the years, corner frequencies have change according with technology, equipment brands and internal requirements on LIS. For example, before 1998, the LIS's network was made of Kinemetrics type instrumentation only. The default filtering from the K2 and ETNA strong motion records from Vol2 format was 0.12 to $47 \mathrm{~Hz}$. When Reftek was introduced in 2010, the range was set at 0.1 to $40 \mathrm{~Hz}$. After 2017, when the SMA took care of the automatic signal processing, it was decided that the range 0.05 to $25 \mathrm{~Hz}$ best fitted the needs for most engineering purposes in Costa Rica. In this way, new technologies such as Guralp and Nanometrics that were later introduced could be used with common values. It is recommendable for the reader to take care when this parameter is sensitive and read the corner frequencies for each record. 
122 In addition to the database and the catalog, we computed a series of intensity measures (IMs) based on 123 ground motion time-histories (Table 2) and peak responses (Table 3). The IMs for each record are also 124 available in the LIS-UCR website (see Data and Resources). The IMs based on time histories are available 125 in a single table where each column represents a single IM. In the case of the IMs based on peak responses, 126 they were calculated with absolute spectral acceleration (SA) and a 5\% damping. Despite the most 127 commonly used IM in Ground Motion Prediction Equations (GMPE) is the pseudo-spectral acceleration 128 (PSA), we estimate the SA with the Nigam and Jennings (1969) exact solution of the differential equation 129 governing the response. For small damping, these two IMs are equivalent (Chopra, 2007). They are 130 presented in single tables as a function of several oscillator periods.

131 We used the acceleration time-histories to calculate the IMs in Table 2. They have been widely used in the 132 development of ground-motion prediction equations and seismic hazard studies (Boore et al., 1997; 133 Watson-Lamprey and Boore, 2007; Mezcua et al., 2008; Schmidt-Díaz, 2014; Douglas, 2017), as well as 134 in the evaluation of expected damage (Park et al., 1987; Kostinakis et al., 2015; Muin and Mosalam, 2017). 135 Figure 6 shows the relation between PGA ( $P G A_{N O O E}, P G A_{N 90 E}$ and $P G A_{Z}$ from Table 2$)$ and hypocentral 136 distance in the database. There are 7413 individual time-histories corresponding to the 2471 records. Of 137 them, $39.5 \%$ have a PGA larger than $10 \mathrm{~cm} / \mathrm{s}^{2}$. Comparing the mean values of several PGA definitions, we 138 got differences of $1.45 \%$ between PGA $\mathrm{Larger}_{3)}$ and $\mathrm{PGA}_{\mathrm{Larger}(2)}$, and $12.5 \%, 15.6 \%$ and $14.0 \%$ between $139 \mathrm{PGA}_{\mathrm{Larger}(2)}$ and $\mathrm{PGA}_{\mathrm{N} 00 \mathrm{E}}, \mathrm{PGA}_{\mathrm{N} 90 \mathrm{E}}$, and $\mathrm{PGA}_{\mathrm{GM}}$ respectively. Figure 7 shows the relation for the rest of the 140 IMs with hypocentral distance.

141 The IMs from peak responses in Table 3 are commonly used in the development of GMPE and hazard maps 142 (Douglas, 2017). The $\mathrm{SA}_{\mathrm{GM}}$ (where GM means geometric mean) has gained popularity in the development 143 of GMPEs in recent years (Douglas, 2003; Campbell and Bozorgnia, 2008; Bindi et al., 2011) because the 144 dispersion in the averaging procedure in GMPE is significantly reduced (Baker and Cornell, 2006; Watson145 Lamprey and Boore, 2007; Stewart et al., 2011). However, this IM has a dependence on the recording 
sensor orientation (this means that if the recording sensor is oriented along the polarization direction, the

147 GM of the response spectra of the as-recorded ground motion tends to zero, Boore et al. 2006). The

148 SA $_{\text {GMRotDpp }}$ and the SA $A_{\text {GMRotIpp }}$ developed by Boore et al. (2006) (where GM means geometric mean, Rot:

149 rotation, D and I: period-dependent and independent rotations, and $\mathrm{pp}$ is the percentile) were proposed in

150 order to eliminate the sensor orientation dependency of the $\mathrm{SA}_{\mathrm{GM}}$. The IM SA $\mathrm{G}_{\mathrm{GMRotlpp}}$, for the 50th percentile

151 (SA $\left.\mathrm{GMRt50}_{\mathrm{G}}\right)$, was used as an intensity parameter in the Next Generation Attenuation (NGA) project (Chiou

152 et al., 2008; Power et al., 2008). Later on, Boore (2010) proposed the usage of the orientation-independent

$153 \mathrm{SA}_{\mathrm{RotDpp}}$ and $\mathrm{SA}_{\mathrm{RotIp}} \mathrm{IMs}$ without computing the geometric mean. Finally, the SA $\mathrm{R}_{\mathrm{R} D 50} \mathrm{IM}$ was used to

154 develop the NGA-West2 (Boore et al., 2013; Bozorgnia et al., 2014) and NGA-East (PEER, 2015) GMPEs

155 models.

156 Figure 8 shows a comparison between the rotated spectra and the SARotD100 IM (following Boore (2010))

157 for the 2012 Nicoya earthquake at GNSR station. It is clear from the figure that the $\mathrm{SA}_{\mathrm{RotD} 100}$ is the envelope

158 of the rotated spectra. Because this IM represents the maximum value of the vector composition, it could

159 be used for the design (or risk assessment) of structures of special importance such as historical-cultural

160 heritage buildings or other high-risk constructions (Pinzón, Pujades, Hidalgo-Leiva, et al., 2018). Figure 9

161 shows the rest of IMs: $\mathrm{SA}_{\mathrm{RotD100}}, \mathrm{SA}_{\mathrm{Larger}}, \mathrm{SA}_{\mathrm{GMRotD50}}, \mathrm{SA}_{\mathrm{GMRot50}}, \mathrm{SA}_{\mathrm{RotD} 50}$, and $\mathrm{SA}_{\mathrm{GM}}$ calculated in the in

162 the range of $0.10 \mathrm{~s}$ to $0.25 \mathrm{~s}$. $\mathrm{SA}_{\mathrm{GMRotD} 50}, \mathrm{SA}_{\mathrm{GMRot} 50}$ and $\mathrm{SA}_{\mathrm{RotD50}}$ correspond to the median values of the

163 rotated spectra and have similar values compared to $\mathrm{SA}_{\mathrm{GM}} . \mathrm{SA}_{\mathrm{RotD} 100}$ and $\mathrm{SA}_{\mathrm{Larger}}$ represent the maximum

164 spectral values. $S A_{\text {RotD100 }}$ is $9 \%$ larger than $\mathrm{SA}_{\text {Larger }}$ on average for the entire database. A statistical summary

165 for all the IMs can be found on the LIS-UCR website (see Data and Resources).

\section{Conclusions}

167 The database presented in this paper contains 2471 three-component digitally recorded strong-motion 168 records from the last 20 years in Costa Rica. They correspond to 155 earthquakes with maximum 169 hypocentral distances of $400 \mathrm{~km}$. Data will continue to be added as new earthquakes get recorded by the 170 LIS-UCR network. In addition, a catalog with earthquake and station metadata is also available. Several 
171 time-history IMs and peak responses were also calculated for each component. The IMs will be useful for

172 developing new seismic hazard studies for the region or for updating the current GMPEs established for

173 Costa Rica (Schmidt-Díaz, 2014). The database, the catalog with the metadata, and the estimated IMs are

174 available at the LIS-UCR website (see Data and Resources).

\section{Data and Resources}

176 The link to the LIS-UCR website is http://www.lis.ucr.ac.cr/. A table with the site conditions of each station

177 is available in the following link: http://www.crsmd.lis.ucr.ac.cr/?id=Estaciones. To request the database

178 of accelerograms please access the following link: http://www.crsmd.lis.ucr.ac.cr/?id=BD, and fill out the

179 form or send an e-mail to lis.inii@ucr.ac.cr.

180 The catalog is available at http://www.crsmd.lis.ucr.ac.cr/?id=BD. The IMs and statistical summary can be 181 found in the following link: http://crsmd.lis.ucr.ac.cr/crsmdb.zip.

\section{Acknowledgments}

183 This research was partially funded by the National Emergency and Risk Prevention Law $\mathrm{N}^{\circ} 8933$ from

184 Costa Rica, the UCREA funds from the University of Costa Rica through the project referenced as B9780

185 and the Spanish Government's Ministry of Economy and Competitiveness (MINECO) through the project 186 referenced as CGL2015-65913-P. Luis A. Pinzón is supported by a Ph.D. scholarship grant from the

187 Government of Panama's Institute for the Training and Development of Human Resources (IFARHU) and 188 the National Secretariat of Science, Technology, and Innovation (SENACYT). 
Alvarado, G. E. et al., 2017, The new Central American seismic hazard zonation: Mutual consensus based on up today seismotectonic framework, Tectonophysics, 721, no. October, 462-476, doi: 10.1016/j.tecto.2017.10.013.

Arias, A., 1970, A measure of earthquake intensity, Cambridge, MA, M.I.T. Press, 438-483.

Arroyo, M., K. Godínez, and L. Linkimer, 2017, Completitud del catálogo de la red sismológica nacional de Costa Rica durante 1975-2014, Bol. Geol., 39, no. 3, 87-98, doi: 10.18273/revbol.v39n32017006.

ASCE, 2017, Minimum Design Loads and Associated Criteria for Buildings and Other Structures (ASCE/SEI 7-16) Reston, VA, doi: 10.1061/9780784414248.

Baker, J. W., and C. A. Cornell, 2006, Which Spectral Acceleration Are You Using?, Earthq. Spectra, 22, no. 2, 293-312, doi: 10.1193/1.2191540.

Beyer, K., and J. J. Bommer, 2006, Relationships between median values and between aleatory variabilities for different definitions of the horizontal component of motion, Bull. Seismol. Soc. Am., 96, no. 4 A, 1512-1522, doi: 10.1785/0120050210.

Bindi, D., F. Pacor, L. Luzi, R. Puglia, M. Massa, G. Ameri, and R. Paolucci, 2011, Ground motion prediction equations derived from the Italian strong motion database, Bull. Earthq. Eng., 9, no. 6, 1899-1920, doi: 10.1007/s10518-011-9313-z.

Bolt, B. A., 1973, Duration of strong ground motion, in 5th World Conference on Earthquake Engineering, 1304-1313.

Bommer, J. J., A.-S. Elnashai, and A. G. Weir, 2000, Compatible acceleration and displacement spectra for seismic design codes, in 12th World Conference on Earthquake Engineering, paper no. 207. 
Boore, D. M., 2010, Orientation-Independent, Nongeometric-Mean Measures of Seismic Intensity from Two Horizontal Components of Motion, Bull. Seismol. Soc. Am., 100, no. 4, 1830-1835, doi: $10.1785 / 0120090400$.

Boore, D. M., W. B. Joyner, and T. E. Fumal, 1997, Equations for estimating horizontal response spectra and peak acceleration from western North American earthquakes: A summary of recent work, Seismol. Res. Lett., no. 68, 128-153.

Boore, D. M., and T. Kishida, 2016, Relations Between Some Horizontal-Component Ground-Motion Intensity Measures Used In Practice 1, Bull. Seismol. Soc. Am., 107, no. 1, 334-343, doi: $10.1785 / 0120160250$.

Boore, D. M., J. P. Stewart, E. Seyhan, and G. M. Atkinson, 2013, NGA-West2 Equations for Predicting Response Spectral Accelerations for Shallow Crustal Earthquakes, Pacific Earthquake Engineering Research Center, California.

Boore, D. M., J. Watson-Lamprey, and N. A. Abrahamson, 2006, Orientation-independent measures of ground motion, Bull. Seismol. Soc. Am., 96, no. 4 A, 1502-1511, doi: 10.1785/0120050209.

Bozorgnia, Y. et al., 2014, NGA-West2 Research Project, Earthq. Spectra, 140227055104009, doi: 10.1193/072113EQS209M.

Bradley, B. A., and J. W. Baker, 2015, Ground motion directionality in the 2010-2011 Canterbury earthquakes, Earthq. Eng. Struct. Dyn., 44, 371-384, doi: 10.1002/eqe.2474.

Campbell, K. W., and Y. Bozorgnia, 2008, NGA ground motion model for the geometric mean horizontal component of PGA, PGV, PGD and 5\% damped linear elastic response spectra for periods ranging from 0.01 to 10 s, Earthq. Spectra, 24, no. 1, 139-171, doi: 10.1193/1.2857546.

CFIA, 2016, Código Sísmico de Costa Rica 2010 (Revisión 2014). Editorial Tecnológica de Costa Rica, Cartago, Costa Rica. 
Chiou, B., R. Darragh, N. Gregor, and W. Silva, 2008, NGA project strong-motion database, Earthq. Spectra, 24, no. 1, 23-44, doi: 10.1193/1.2894831.

Chopra, A. K., 2007. Dynamics of Structures: Theory and Applications to Earthquake Engineering, Prentice Hall, New Jersey.

DeShon, H. R., S. Y. Schwartz, S. L. Bilek, L. M. Dorman, V. Gonzalez, J. M. Protti, E. R. Flueh, and T. H. Dixon, 2003, Seismogenic zone structure of the southern Middle America Trench, Costa Rica, J. Geophys. Res. Solid Earth, 108, no. B10, doi: 10.1029/2002jb002294.

Dobry, R., I. M. Idriss, and E. Ng, 1978, Duration characteristics of horizontal components of strongmotion earthquake records, Bull. Seismol. Soc. Am., 68, no. 5, 1487-1520.

Douglas, J., 2003, Earthquake ground motion estimation using strong-motion records: a review of equations for the estimation of peak ground acceleration and response spectral ordinates, EarthScience Rev., 61, nos. 1-2, 43-104, doi: 10.1016/S0012-8252(02)00112-5.

Douglas, J., 2017, Ground motion prediction equations 1964-2016, Glasgow, UK.

Garini, E., and G. Gazetas, 2013, Damage potential of near-fault records: Sliding displacement against conventional “Intensity Measures," Bull. Earthq. Eng., 11, no. 2, 455-480, doi: 10.1007/s10518012-9397-0.

Goes, S. D. B., A. A. Velasco, S. Y. Schwartz, and T. Lay, 1993, The April 22, 1991, Valle de la Estrella, Costa Rica (Mw=7.7) earthquake and its tectonic implications: a broadband seismic study, J. Geophys. Res., 98, no. B5, 8127-8142, doi: 10.1029/93JB00019.

Goldstein, P., D. Dodge, M. Firpo, and L. Minner, 2003, SAC2000: Signal processing and analysis tools for seismologists and engineers, in International Handbook of Earthquake and Engineering Seismology W. H. K. Lee, H. Kanamori, P. C. Jennings, and C. Kisslinger (Editors), Academic 
Press, London, 1613-1614.

260

261

262

263

264

265

266

267

268

Guangwei Fan, S. L. Beck, and T. C. Wallace, 1993, The seismic source parameters of the 1991 Costa Rica aftershock sequence: evidence for a transcurrent plate boundary, J. Geophys. Res., 98, no. B9, 15759, doi: 10.1029/93JB01557.

Guendel, F., and M. Protti, 1998, Sismicidad y sismotectónica de América Central, Física la Tierra, 10, nos. 0214-4557, 19-51.

Hayes, G. P., D. J. Wald, and R. L. Johnson, 2012, Slab1.0: A three-dimensional model of global subduction zone geometries, J. Geophys. Res. Solid Earth 117, no. 1, 1-15, doi: 10.1029/2011JB008524.

Housner, G. W., 1975, Measures of severity of earthquake ground shaking, in Proc. U.S. Natl. Conf. Earthquake Eng., 25-33.

Husid, L. R., 1969, Características de terremotos. Análisis general., Rev. del IDIEM, 8, no. 1, 21-42.

Kostinakis, K. G., A. M. Athanatopoulou, and K. Morfidis, 2015, Correlation between ground motion intensity measures and seismic damage of 3D R/C buildings, Eng. Struct., 82, 151-167, doi: 10.1016/j.engstruct.2014.10.035.

Mezcua, J., R. M. García Blanco, and J. Rueda, 2008, On the strong ground motion attenuation in Spain, Bull. Seismol. Soc. Am., 98, no. 3, 1343-1353, doi: 10.1785/0120070169.

Montero, W., 2001, Neotectónica De La Región Central De Costa Rica, Rev. Geol. Am. Cent., 24, 29-56.

Moya Fernández, A., 2018, Accelerographic Monitoring System of the Earthquake Engineering Laboratory, Rev. Ing., 28, no. 1, 96-114, doi: 10.15517/ri.v28i1.30874.

Moya Fernández, A., 2006, Nuevo formato de datos para el Laboratorio de Ingeniería Sísmica del Instituto de Investigaciones en Ingeniería de la Universidad de Costa Rica, Rev. Ing., 16, no. 2, 63- 
282

283

284

285

286

287

288

289

290

291

292

293

294

295

296

297

298

299

300

301

302

Muin, S., and K. M. Mosalam, 2017, Cumulative Absolute Velocity as a Local Damage Indicator of Instrumented Structures, Earthq. Spectra, 33, no. 2, 641-664, doi: 10.1193/090416EQS142M.

Nigam, N.C. and Jennings, P. C., 1969, Calculation of Response Spectra from Strong-Motion Earthquake Records, Bull. Seismol. Soc. Am. 59, no. 2, 909-922.

Norabuena, E. et al., 2004, Geodetic and seismic constraints on some seismogenic zone processes in Costa Rica, J. Geophys. Res. Solid Earth, 109, no. 11, 1-25, doi: 10.1029/2003JB002931.

Park, Y. J., A. H. S. Ang, and Y. K. Wen, 1987, Damage-Limiting Aseismic Design of Buildings., Earthq. Spectra, 3, no. 1, 1-26, doi: 10.1193/1.1585416.

PEER, 2015, NGA-East : Median Ground-Motion Models for the Central and Eastern North America Region, Peer Rep. 2015/04, no. April 2015.

Pinzón, L. A., L. G. Pujades, S. A. Diaz, and R. E. Alva, 2018, Do Directionality Effects Influence Expected Damage? A Case Study of the 2017 Central Mexico Earthquake, Bull. Seismol. Soc. Am., 108, no. 5A, 2543-2555, doi: 10.1785/0120180049.

Pinzón, L. A., L. G. Pujades, D. A. Hidalgo-Leiva, and S. A. Diaz, 2018, Directionality models from ground motions of Italy, Ing. Sismica, 35, no. 3, 43-63.

Pinzón, L. A., Vargas-Alzate, Y. F., Pujades, L. G., and Diaz, S. A., 2020, A drift-correlated ground motion intensity measure: Application to steel frame buildings. Soil Dynamics and Earthquake Engineering, 132, 106096. doi: 10.1016/j.soildyn.2020.106096

Power, M., B. S. J. Chiou, N. A. Abrahamson, Y. Bozorgnia, T. Shantz, and C. Roblee, 2008, An overview of the NGA project, Earthq. Spectra, 24, no. 1, 3-21, doi: 10.1193/1.2894833.

Quintero, R., and F. Güendel, 2000, Stress field in Costa Rica, Central America, J. Seismol., 4, no. 3, 
Reed, J. W., and R. P. Kassawara, 1990, A criterion for determining exceedance of the Operating Basis Earthquake, Nucl. Eng. Des., 123, nos. 2-3, 387-396.

Sarma, S. K., 1971, Energy flux of strong earthquakes, Tectonophysics, 11, no. 3, 159-172.

Sarma, S. K., and K. S. Yang, 1987, An evaluation of strong motion records and a new parameter A95, Earthq. Eng. Struct. Dyn., 15, 119-132, doi: 10.1002/eqe.4290150109.

Schmidt-Díaz, V., 2014, Ground motion prediction models for Central America using data from 1972 to 2010, Rev. Geológica América Cent., 50, 7-37.

Schmidt-Díaz, V., 2011, Soil classification based on spectral ratios where Central American accelerographic stations are located. Cases of El Salvador, Nicaragua and Costa Rica, Rev.

Schmidt-Díaz, V., D. A. Hidalgo-Leiva, A. L. Acuña, A. Moya Fernández, E. Cordero, S. C., and E. Geológica América Cent., no. 44, 9-26, doi: 10.15517/rgac.v0i44.3443. codes, Earthq. Spectra, 27, no. 3, 927-937, doi: 10.1193/1.3608001.

Sucuoğlu, H., and A. Nurtuğ, 1995, Earthquake ground motion characteristics and seismic energy dissipation, Earthq. Eng. Struct. Dyn., 24, no. 9, 1195-1213, doi: 10.1002/eqe.4290240903. the Seismological Society of America, 108(1), 371-379, doi: 10.1785/0120170174. Bull. Seismol. Soc. Am., 65, no. 3, 581-626. 
325 Tso, W. K., T. J. Zhu, and A. C. Heidebrecht, 1992, Engineering implication of ground motion A/V ratio, 326 Soil Dyn. Earthq. Eng., 11, no. 3, 133-144.

327 Watson-Lamprey, J. A., and D. M. Boore, 2007, Beyond SaGMRotI: Conversion to SaArb, SaSN, and SaMaxRot, Bull. Seismol. Soc. Am., 97, no. 5, 1511-1524, doi: 10.1785/0120070007.

329 Zhao, J. X., K. Irikura, J. Zhang, Y. Fukushima, P. G. Somerville, A. Asano, Y. Ohno, T. Oouchi, T. 330 Takahashi, and H. Ogawa, 2006, An empirical site-classification method for strong-motion stations 331 in Japan using H/V response spectral ratio, Bull. Seismol. Soc. Am., 96, no. 3, 914-925, doi: $332 \quad 10.1785 / 0120050124$. 


\section{Authors mailing addresses}

\section{Aarón Moya Fernández}

Email: cesar.moya@ucr.ac.cr

Address: Laboratorio de Ingeniería Sísmica, Ciudad de la Investigación Universidad de Costa Rica, San Pedro, San José, Costa Rica

\section{Luis A. Pinzón}

Email: luis.pinzon@upc.edu

Address: C. Jordi Girona 1-3 (Campus Nord-UPC), D2 303, 08034, Barcelona, Spain

Victor Schmidt-Díaz

Email: victor.schmidt@ucr.ac.cr

Address: Laboratorio de Ingeniería Sísmica, Ciudad de la Investigación Universidad de Costa Rica, San Pedro, San José, Costa Rica

\section{Diego Hidalgo-Leiva}

Email: diego.hidalgo@ucr.ac.cr

Address: Laboratorio de Ingeniería Sísmica, Ciudad de la Investigación Universidad de Costa Rica, San Pedro, San José, Costa Rica

\section{Luís G. Pujades}

Email: 1luis.pujades@upc.edu

Address: C. Jordi Girona 1-3 (Campus Nord-UPC), D2 303, 08034, Barcelona, Spain 


\section{Tables}

Table 1 Magnitude, depth and epicentral distance statistics for the entire database. Number and percentage of three-components records per interval.

\begin{tabular}{|c|c|c|c|c|c|c|}
\hline \multirow{2}{*}{ Magnitude $\left(M_{w}\right)$} & \multicolumn{6}{|c|}{ Depth (km) } \\
\hline & $<10$ & $10-25$ & $25-50$ & $50-100$ & $100-150$ & $\geq 150$ \\
\hline $3.0-4.0$ & $38(1.5 \%)$ & $27(1.1 \%)$ & - & - & - & - \\
\hline $4.0-5.0$ & $76(3.1 \%)$ & $348(14.1 \%)$ & $365(14.8 \%)$ & $108(4.4 \%)$ & - & - \\
\hline $5.0-6.0$ & $57(2.3 \%)$ & $472(19.1 \%)$ & $229(9.3 \%)$ & $144(5.8)$ & - & $28(1.1 \%)$ \\
\hline $6.0-7.0$ & $12(0.5 \%)$ & $232(9.4 \%)$ & $227(9.2 \%)$ & $7(0.2 \%)$ & $30(1.2 \%)$ & - \\
\hline$\geq 7.0$ & - & $71(2.9 \%)$ & - & - & - & - \\
\hline \multirow{2}{*}{ Magnitude $\left(M_{w}\right)$} & \multicolumn{6}{|c|}{ Epicentral distance (km) } \\
\hline & $<10$ & $10-25$ & $25-50$ & $50-100$ & $100-150$ & $\geq 150$ \\
\hline $3.0-4.0$ & $17(0.7 \%)$ & $31(1.3 \%)$ & $5(0.2 \%)$ & $8(0.3 \%)$ & $4(0.2 \%)$ & - \\
\hline $4.0-5.0$ & $30(1.2 \%)$ & $130(5.3 \%)$ & $325(13.1 \%)$ & $326(13.2 \%)$ & $53(2.1 \%)$ & $33(1.3 \%)$ \\
\hline $5.0-6.0$ & $18(0.7 \%)$ & $58(2.3 \%)$ & $170(6.9 \%)$ & $316(12.8 \%)$ & $182(7.4 \%)$ & $186(7.5 \%)$ \\
\hline $6.0-7.0$ & $3(0.1 \%)$ & $12(0.5 \%)$ & $26(1.0 \%)$ & $104(4.2 \%)$ & $75(3.0 \%)$ & $288(11.7 \%)$ \\
\hline$\geq 7.0$ & - & $1(0.1 \%)$ & $1(0.1 \%)$ & $8(0.3 \%)$ & $13(0.5 \%)$ & $48(2.0 \%)$ \\
\hline
\end{tabular}


Table 2 List of intensity measures based on ground motion time histories

\begin{tabular}{|c|c|c|c|}
\hline Intensity measure & Acronym & Formulation & Units \\
\hline Peak ground acceleration & $\begin{array}{c}P G A_{N O O E} \\
P G A_{N 90 E} \\
P G A_{Z}\end{array}$ & $\begin{array}{c}\max \left|a_{N 00 E}(t)\right| \\
\max \left|a_{N 90 E}(t)\right| \\
\max \left|a_{Z}(t)\right|\end{array}$ & $\mathrm{cm} / \mathrm{s}^{2}$ \\
\hline $\begin{array}{c}\text { Larger value of the two horizontal components of } \\
\text { acceleration (Douglas, 2003; Beyer and Bommer, 2006; } \\
\text { Pinzón, Pujades, Hidalgo-Leiva, et al., 2018) }\end{array}$ & $P G A_{\text {Larger }(2)}$ & $\max \left[\begin{array}{l}\max \left|a_{N 00 E}(t)\right| \\
\max \left|a_{N 90 E}(t)\right|\end{array}\right]$ & $\mathrm{cm} / \mathrm{s}^{2}$ \\
\hline Larger value of the three components of acceleration & $P G A_{\text {Larger }(3)}$ & $\max \left[\begin{array}{c}\max \left|a_{N 00 E}(t)\right| \\
\max \left|a_{N 90 E}(t)\right| \\
\max \left|a_{z}(t)\right|\end{array}\right]$ & $\mathrm{cm} / \mathrm{s}^{2}$ \\
\hline $\begin{array}{c}\text { Geometric mean of the PGA of the two horizontal } \\
\text { components (Beyer and Bommer, 2006; Pinzón, Pujades, } \\
\text { Hidalgo-Leiva, et al., 2018) }\end{array}$ & $P G A_{G M}$ & $\sqrt{P G A_{N O O E} * P G A_{N 90 E}}$ & $\mathrm{~cm} / \mathrm{s}^{2}$ \\
\hline Peak ground velocity & $P G V$ & $\max |v(t)|$ & $\mathrm{cm} / \mathrm{s}$ \\
\hline $\begin{array}{l}\text { PGV-to-PGA ratio (Tso et al., 1992; Sucuoğlu and Nurtuğ, } \\
\text { 1995; Bommer et al., 2000) }\end{array}$ & $P G V / P G A$ & $\frac{\max |v(t)|}{\max |a(t)|}$ & $\mathrm{s}$ \\
\hline Arias intensity (Arias, 1970) & $I_{A}$ & $\frac{\pi}{2 g} \int_{t_{i}}^{t_{f}} a(t)^{2} d t$ & $\mathrm{~cm} / \mathrm{s}$ \\
\hline $\begin{array}{l}\text { Root-mean-square (RMS) of acceleration (Housner, 1975; } \\
\qquad \text { Dobry et al., 1978) }\end{array}$ & $a c c_{R M S}$ & $\sqrt{\frac{1}{\Delta} \int_{t_{5 \%}}^{t_{95 \%}} a(t)^{2} d t}$ & $\mathrm{~g}$ \\
\hline $\begin{array}{l}\text { Root-mean-square (RMS) of velocity (Garini and Gazetas, } \\
\qquad 2013 \text {; Kostinakis et al., 2015) }\end{array}$ & $v e l_{R M S}$ & $\sqrt{\frac{1}{\Delta} \int_{t_{5 \%}}^{t_{95 \%}} v(t)^{2} d t}$ & $\mathrm{~cm} / \mathrm{s}$ \\
\hline $\begin{array}{l}\text { Specific energy density (Sarma, 1971; Sarma and Yang, } \\
\text { 1987) }\end{array}$ & $S E D$ & $\int_{t_{i}}^{t_{f}} v(t)^{2} d t$ & $\mathrm{~cm}^{2} / \mathrm{s}$ \\
\hline Characteristic intensity (Park et al., 1987) & $I_{C}$ & $\operatorname{acc}_{R M S}{ }^{1.5} \sqrt{t_{f}}$ & - \\
\hline Cumulative absolute velocity (Reed and Kassawara, 1990) & $C A V$ & $\int_{t_{i}}^{t_{f}}|a(t)| d t$ & $\mathrm{~cm} / \mathrm{s}$ \\
\hline $\begin{array}{l}\text { Significant duration (Husid, 1969; Bolt, 1973; Housner, } \\
\text { 1975; Trifunac and Brady, 1975), }\end{array}$ & $\Delta$ & $5-95 \%$ of Arias intensity & $\mathrm{s}$ \\
\hline Duration-PGV intensity (Pinzón et al., 2020) & $I_{\triangle-P G V}$ & $P G V^{\alpha} \Delta^{\beta}$ & - \\
\hline
\end{tabular}

- $\quad a(t)$ and $v(t)$ represents the acceleration and velocity time histories of an earthquake.

- $t_{i}$ is the beginning of the record, $t_{f}$ is the total duration of the record.

- $\quad 5 \%$ and $95 \%$ of the Arias intensity marks the beginning ( $t 5 \%)$ and end $\left(t_{95} \%\right)$ of the strong phase. 
Table 3 List of intensity measures based on peak responses

\begin{tabular}{cl}
\hline Intensity measure & \multicolumn{1}{c}{ Definition } \\
\hline$S A_{N O O E}$ and $S A_{N 90 E}$ & $\begin{array}{l}\text { Response spectra of the as-recorded horizontal orthogonal components } \\
\text { The larger of the two horizontal components (Douglas, 2003; Beyer and Bommer, 2006; } \\
\text { Bradley and Baker, 2015; Boore and Kishida, 2016; Pinzón, Pujades, Hidalgo-Leiva, et } \\
\text { al., 2018) }\end{array}$ \\
Geometric mean of the response spectra of the two as-recorded horizontal components \\
(Beyer and Bommer, 2006; Bradley and Baker, 2015; Boore and Kishida, 2016; Pinzón, \\
Pujades, Hidalgo-Leiva, et al., 2018)
\end{tabular}




\section{List of figures}

Figure 1. Station distribution for the LIS-UCR strong-motion network. White lines correspond to administrative divisions by provinces and gray lines to major roads.

Figure 2. Station distribution and soil classification.

Figure 3. Number of ground motions recorded per year.

Figure 4. (a) Magnitude as a function of the hypocentral distance for the 2471 records and (b) magnitude distribution.

Figure 5. Epicenter location for the earthquakes recorded between 1998 and 2019.

Figure 6. Peak ground acceleration as a function of the hypocentral distance for the three as-recorded components.

Figure 7. Several intensity measures as a function of the hypocentral distance: (a) PGV, (b) PGV/PGA, (c)

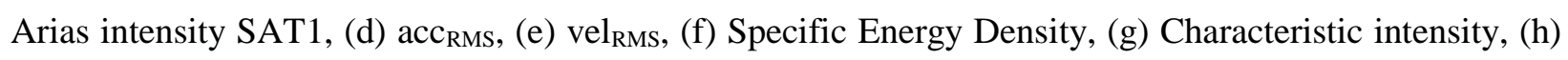
Cumulative Absolute Velocity and (i) Significand duration.

Figure 8. Comparison of the $5 \%$ damped response spectra estimated with RotD100, GM, horizontal acceleration components (NOOE and $\mathrm{N} 90 \mathrm{E})$ and the rotated components ( $\theta^{\circ}$ rot) from the 7.6 Mw Nicoya earthquake recorded at station GNSR, which occurred on 5 September 2012.

Figure 9. Comparison of the 5\% damped response spectra estimated with RotD100, Larger, RotD50, GMRotI50, GMRotD50 and the GM using the 7.6 Mw Nicoya earthquake recorded at station GNSR, which occurred on 5 September 2012. 


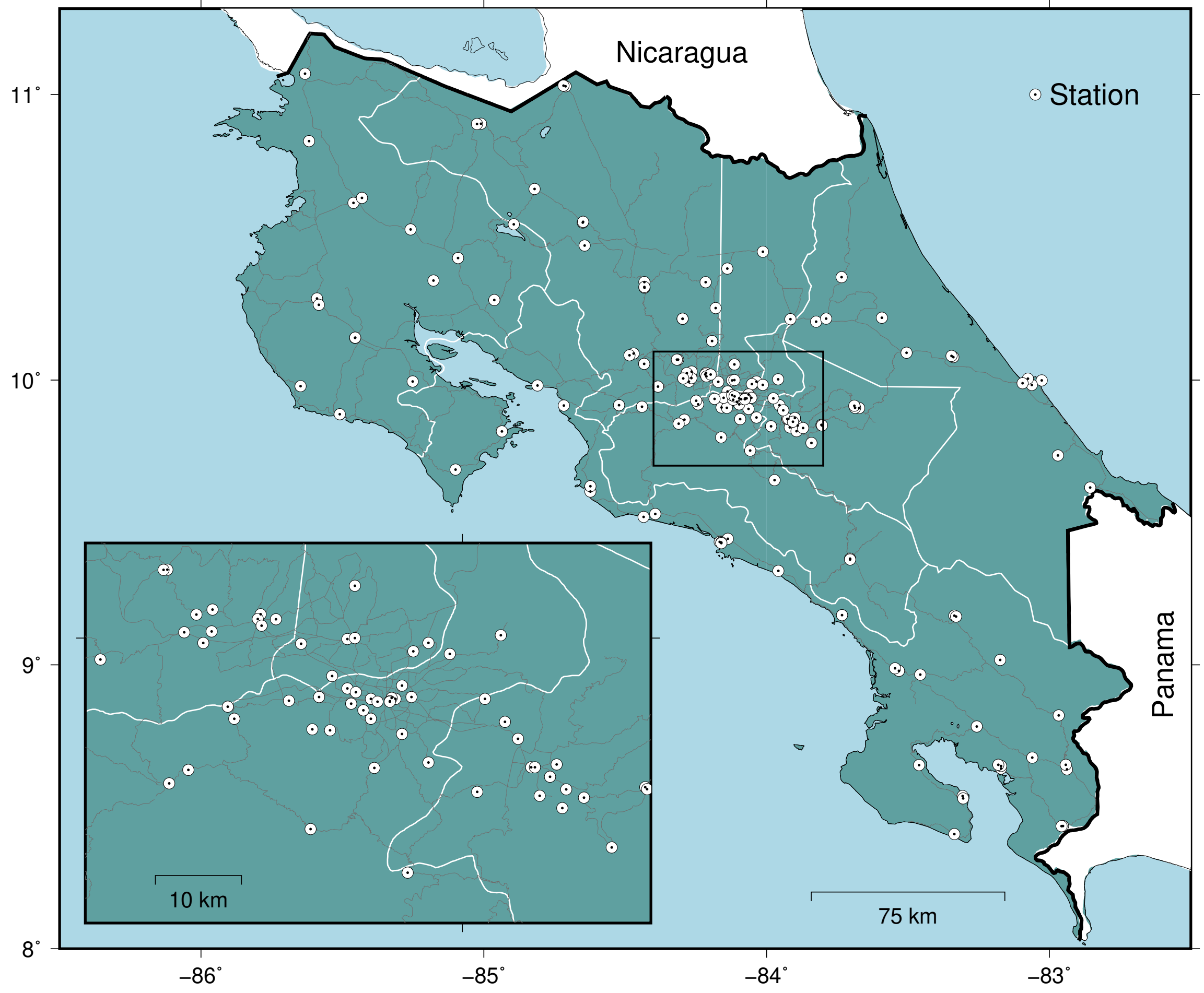




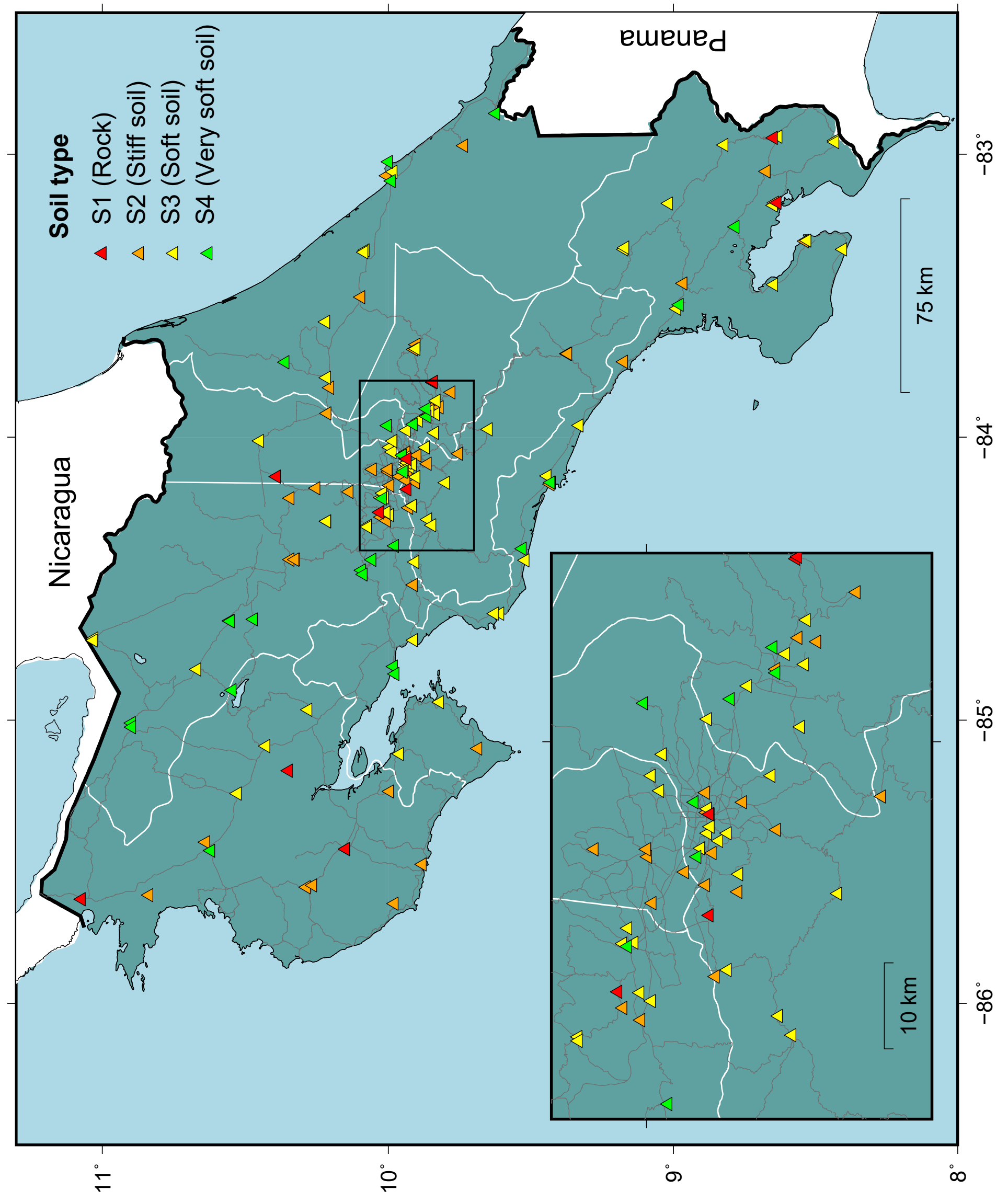




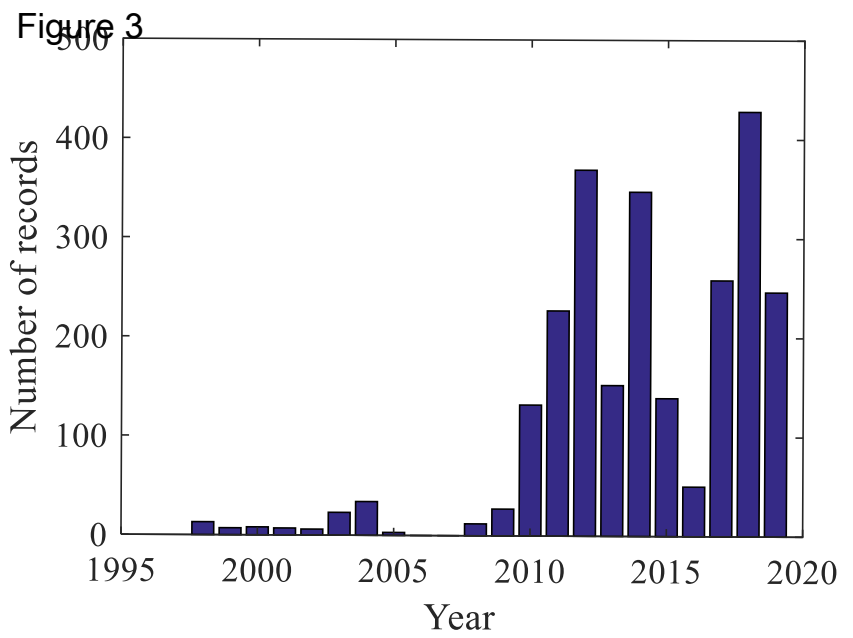


Figure4

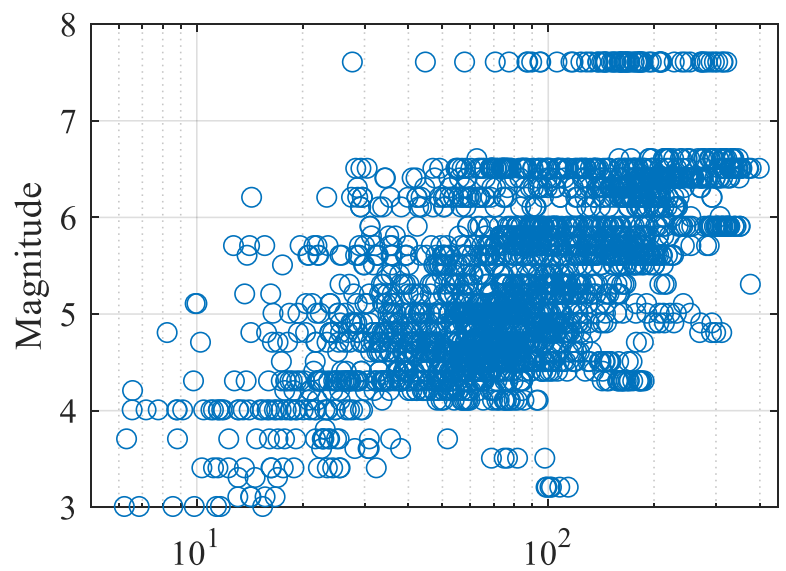

Hypocentral distance $(\mathrm{km})$ (b)

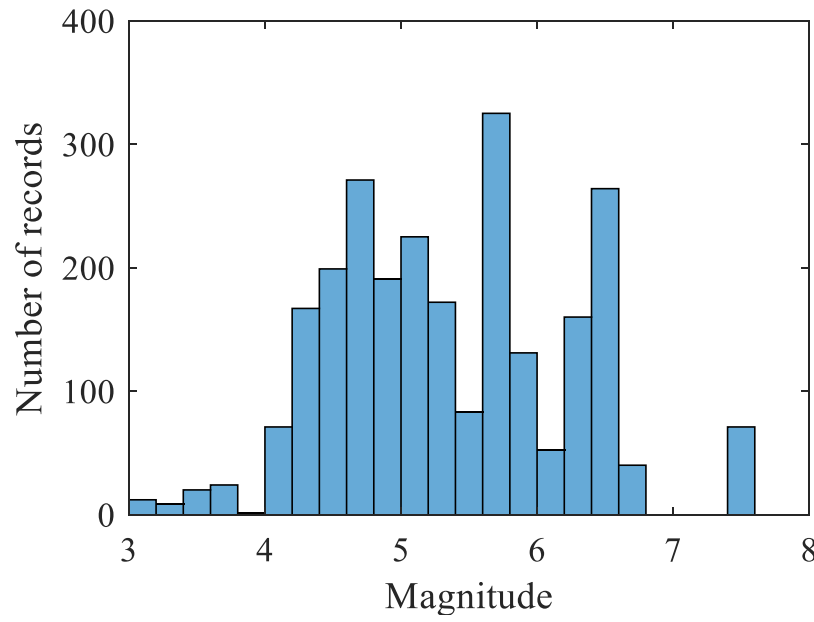




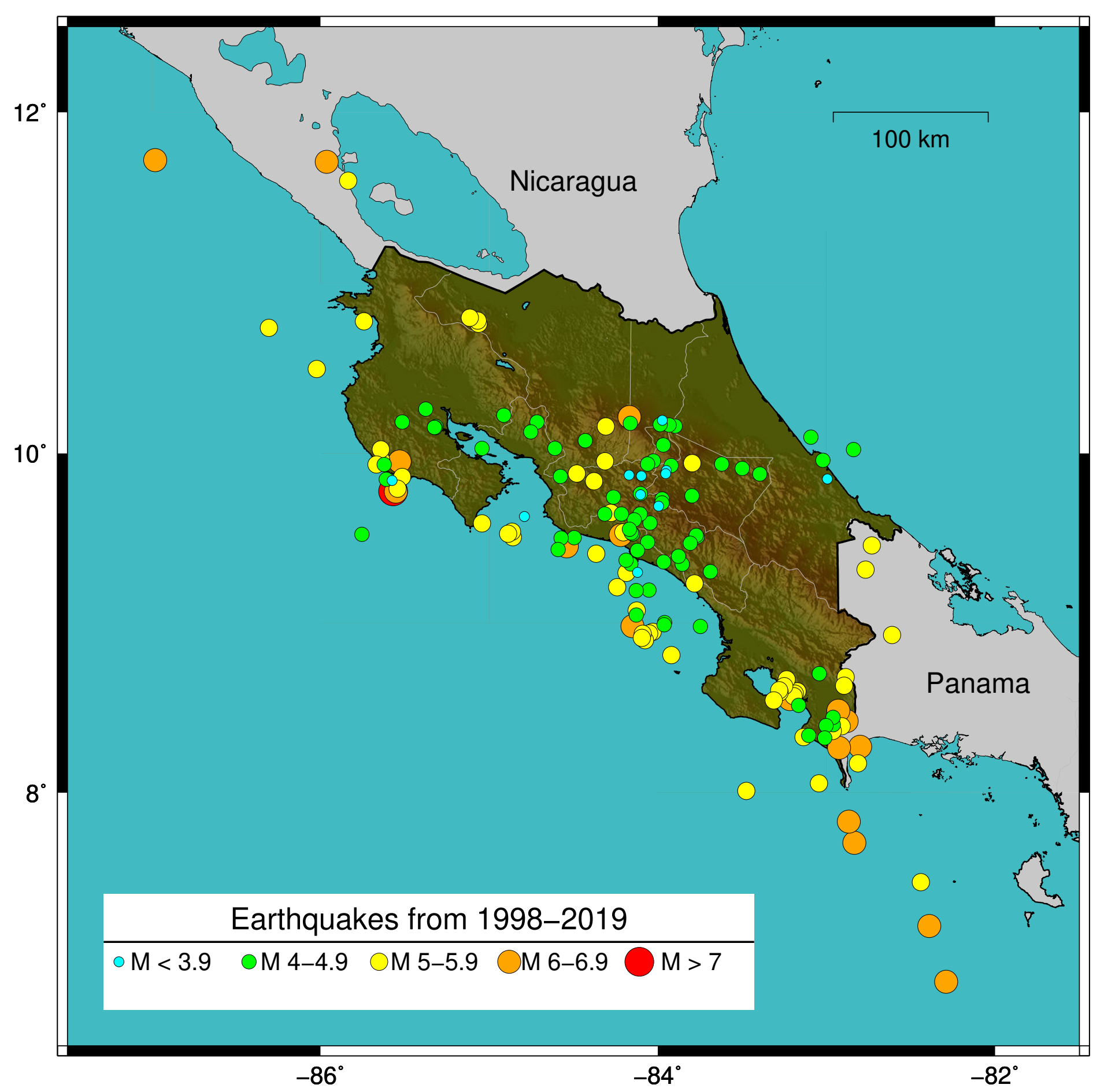


Figure 7

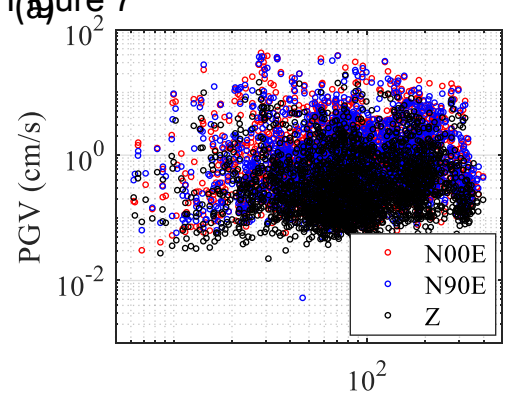

(d) Hypocentral distance $(\mathrm{km})$

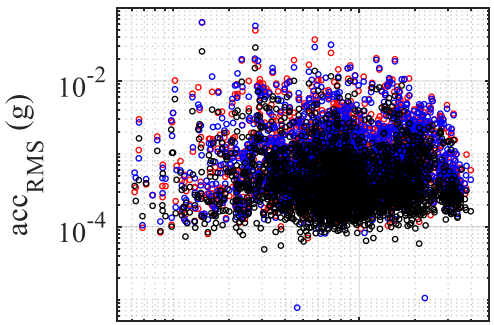

$10^{2}$

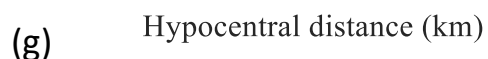

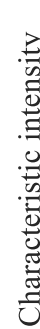

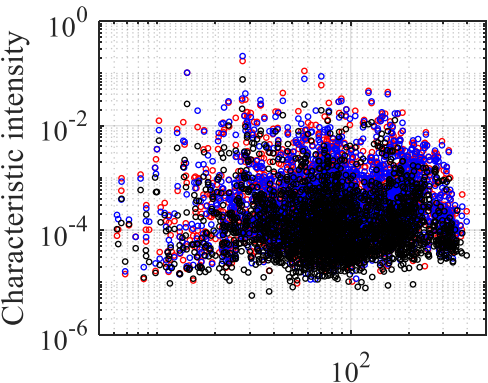

Hypocentral distance $(\mathrm{km})$ (b)
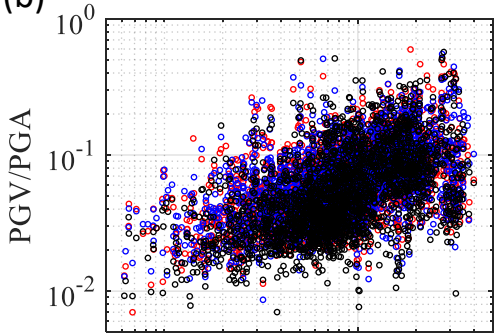

$10^{2}$

(e) Hypocentral distance $(\mathrm{km})$

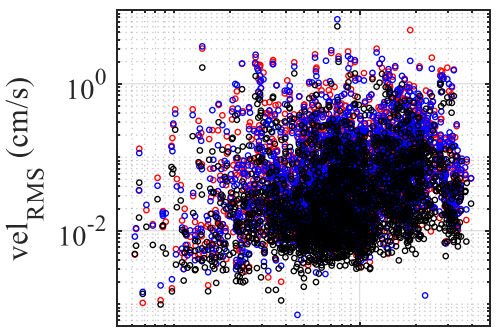

$10^{2}$

(h) Hypocentral distance $(\mathrm{km})$

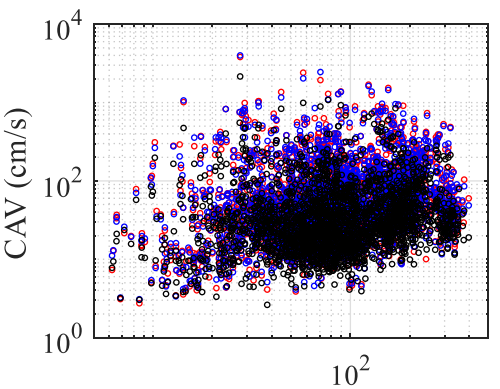

Hypocentral distance $(\mathrm{km})$ (c)

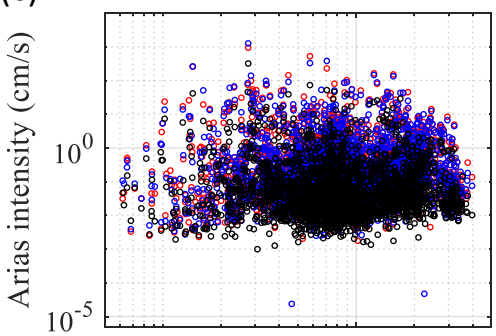

$10^{2}$

(f) Hypocentral distance $(\mathrm{km})$

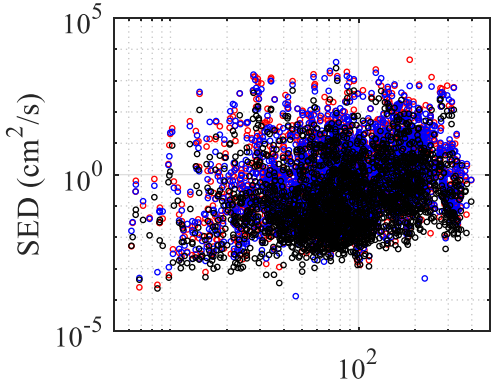

Hypocentral distance $(\mathrm{km})$

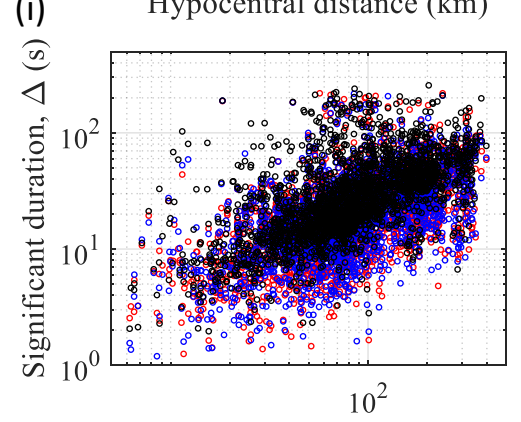

Hypocentral distance $(\mathrm{km})$ 
Fiqure 8

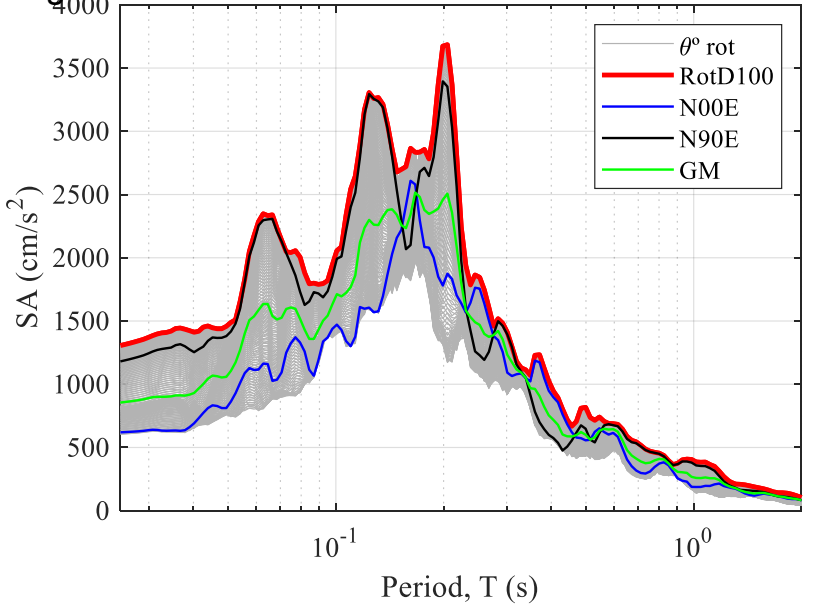


